\title{
IAMJ
}

INTERNATIONAL

AYURVEDIC

MEDICAL JOURNAL

ISSN: 23205091

Impact Factor: 5.344

\section{EVALUATION OF EFFECT OF VAITARANA BASTI AND UPANAHA SWEDA IN LOW BACK ACHE (KATI GRAHA) DUE TO SACROILITIS: A CASE REVIEW}

\author{
$\underline{\text { Swathi N. }}{ }^{1}$, Anup B. Thakar ${ }^{2}$ \\ ${ }^{1} 2^{\text {nd }}$ Year PG Scholar, ${ }^{2}$ Professor and HOD, Director, I/c. Vice-chancellor \\ Dept. of Panchakarma, IPGT\&RA, G.A.U., Jamnagar, Gujarat, India
}

Corresponding Author: swathinudupi@gmail.com

\section{https://doi.org/10.46607/iamj5808102020}

(Published online: October 2020)

Open Access

(C) International Ayurvedic Medical Journal, India 2020

Article Received: 23/09/2020 - Peer Reviewed: 02/10/2020 - Accepted for Publication: 04/10/2020

(A) Check for updates

\begin{abstract}
According to WHO, low backache is one of the leading causes of disability affecting about 540 million people in the world. Objectives: To evaluate the effect of Vaitarana Basti and Upanaha Sweda in Katigraha (low backache) caused due to sacroiliitis. Methods: A female patient aged 28 years suffering from pain and stiffness in low back was taken in this study. Her VAS score was 6 and ODI (Oswestry disability index) was 36 (72\%). The case was diagnosed as sacroiliitis through MRI. She was treated with Vaitarana Basti and Kolakulatthadi Upanaha Sweda. Results: VAS score was reduced to 1 and ODI-10 (20\%). Conclusion: Significant improvement was found in the reduction of pain and stiffness due to Deepana, Pachana and Shoolahara properties of Dravya.
\end{abstract}

Keywords: Sacroilitis, Vaitarana Basti, Upanaha

\section{INTRODUCTION}

Incidences of low back ache is $60-85 \%$ in adults. It is a common complaint in clinical practice and may be caused by wide spectrum of diseases. Sacro-iliac joint is almost always involved in Ankylosing spondylitis.
It is characterized by painful stiffness of the back. Pain may be like a distribution of band across the sacrum and buttocks. Acc. to Ayurveda, when Kevala 
Vata or Saama Vata gets vitiated in Kati Pradesha, it exhibits the symptom of Katigraha.

Objectives: To evaluate the effect of Vaitarana Basti and Upanaha Sweda in Katigraha (low backache) caused due to sacroiliitis.

Methodology: Case Report: A female patient aged 28 years came to OPD (No. PG 71891) of Dept. of Panchakarma, IPGT\&RA, Jamnagar with the complaint of Ruja (pain) and Stambha (stiffness) in low back for 2 years. She took allopathic medications like steroids and painkiller but there was only temporary relief. Since past 1 month, patient also suffering from Suptata (numbness) and Akunchanaprasarane Akshamata (restricted joint movement) in Kati Pradesha and was feeling difficulty in day to day activities. She was admitted in the Female general ward (IPD No.4528) of Panchakarma department, IPGT\&RA Hospital, Jamnagar.

\section{Diagnosis and Assessment:}

Gait- Antalgic., Inspection of Back- Curvature of Spine- Normal, Palpation- Tenderness- Positive in $\mathrm{L}_{5}-\mathrm{S}_{1}$ region., SLR Test- Negative in bilateral lower limbs., Schober's Test- No change in the distance., Claudication distance-200 meters., VAS Score for Pain ${ }^{[1]}-6$ on $0-10$ Scale., Oswestry Disability Index [2]_ $36(72 \%)$ out of 50 .

MRI LS Spine with SI Joints: Bilateral chronic sacroiliitis, more on right side. No evident changes of joint effusion.

Table 1: Rogi Roga Pareeksha

\begin{tabular}{|c|c|c|c|c|c|}
\hline \multicolumn{3}{|c|}{ Rogi Pareeksha } & \multicolumn{3}{|c|}{ Roga-Samprapti Ghataka } \\
\hline 1. & Prikriti & Kaphavataja & 1. & Dosha & Vata, Kapha \\
\hline 2. & Sara & Madhyama & 2. & Dooshya & Rasa, Asthi, Majja \\
\hline 3. & Samhanana & Madhyama & 3. & Srotas & Annavaha, Rasavaha, Asthivaha \\
\hline 4. & Pramana & Pravara & 4. & Srotodushti Prakara & Sanga \\
\hline 5. & Satmya & Madhyama & 5. & Udbhavasthana & Ama Pakwashaya \\
\hline 6. & Satwa & Madhyama & 6. & Vyaktasthana & Kati, Ubhaya Pada \\
\hline 7. & Aharashakti & Avara & 7. & Adhishtana & Asthi, Sandhi \\
\hline 8. & Vyayamashakti & Avara & 8. & Rogamarga & Madhyama \\
\hline 9. & Vaya & Madhyama & 9. & Vyadhi Swabhava & Chirakari \\
\hline & & & 10. & Sadhyasadhyata & Krichrasadhya \\
\hline
\end{tabular}

Diagnosis Katigraha (low back ache) due to bilateral sacroiliitis.

\section{Treatment Plan-}

1. Vaitarana Basti ${ }^{[3]}$ : Ingredients: Guda-24 g., Saidhava lavana-12g., Sneha (Tila Taila)- 48ml., Amleeka- 48g., Gomutra- 100ml., Jala-100ml. Total- $320 \mathrm{ml}$. Preparation was done as per the standard procedure of Niruha Basti. Basti was administered following Sthanika Snehana and Swedana at 9 am in empty stomach for 8 days.

2. Kolakulatthadi Upanaha ${ }^{[4]}$ : Poultice prepared using the ingredients like Tila Taila-20ml., Lashuna- 4 bulbs, Saindhava lavana- 5g., Nimbuka- 1, Kola, Kulattha, Devadaru, Rasna, Masha, Atasi, Tila, Kushta, Vacha, Shatahwa, Yava-10 grams each. Drava Dravya-
Erandamoola Kwatha. Patient was instructed to lie in the prone position on the massage table. Low back area was exposed and skin sensitivity for allergy and temperature was checked. Then prepared poultice pasted over it uniformly about $5 \mathrm{~mm}$. thickness. It was covered with Arka Patra and cotton bandage was tied and removed after 12 hours. It was followed for 8 days.

Results: After the completion of treatment, results were assessed based on subjective and objective parameters. Marked improvement was seen in reduction of Ruja and Stambha. Supti got reduced up to $80 \%$. 
Table 2: Effect of treatment on Objective parameters

\begin{tabular}{|l|l|l|}
\hline Objective Parameters & Before treatment & After treatment \\
\hline 1. Gait & Antalgic & Normal \\
2. Tenderness on palpation & Severe & Mild \\
3. Schober's Test & No change in the distance & Distance increased by $5 \mathrm{cms}$. \\
4. VAS Score for Pain & 6 on $0-10$ Scale & 1 on $0-10$ Scale \\
5. Oswestry Disability Index & $36(72 \%)$ out of 50 & $10(20 \%)$ out of 50 \\
4. Claudication distance & 200 meters & 800 meters-1 kilo meters \\
\hline
\end{tabular}

\section{DISCUSSION}

Vaitarana Basti is indicated in the diseases which are having Amadosha and Vatakapha predominance. It is explained in Chakradatta and Vangasena Samhitha. As per the reference of Chakradatta treatment was followed in this patient which contains Gomutra as Avapa Dravya. Guda (Puraana) is Laghu, Pathya and Anabhishyandi. Saindhava Lavana acts as Deepana, Pachana and Tridoshaghna. Amleeka is Vatakaphahara in nature. Tila Taila is said to be best Vatahara and in Basti it helps to attain homogeneous mixture. Gomutra having Ushna, Teekshna Guna pacifies Kapha Dosha. In this way, Basti eliminates the mala from the body which have undergone liquefaction due to Snehana and Swedana just like a cloth which absorbs the dye from water mixed with Kusumbha plant. Upanaha is a type of Swedana, so it induces hyperthermia which improves local blood and lymphatic circulation and thereby improving local tissue metabolism [5]. It reduces inflammation by modifying secretion of various inflammatory mediators, relaxes local musculature by physical effect of heat, increases the rate of transdermal drug delivery and thereby reduces the pain. Drugs used are having Ushna, Teekshna Guna, Vedanasthapana and Vatakaphahara in nature. Most of the drugs are having Anti-inflammatory and analgesic properties which helped in relieving pain ${ }^{[6]}$.

\section{CONCLUSION}

Low back ache is the major cause of morbidity and sacroiliitis is often an early symptom of Ankylosing spondylitis. Conservative medicine is only for pain management which includes analgesics or corticosteroids. This case study showed Vaitarana Basti and Upanaha Sweda are safe and effective in the management of Katigraha and significant improvement found in quality of life of the patient. There was no any adverse drug effect during and after the course of treatment.

\section{REFERENCES}

1. Michael Ogon et al, Chronic low back pain measurement with visual analogue scales in different settings, March 1996, Volume 64, Issue 3:425-428

2. Fairbank JCT, Pynsent PB. The Oswestry Disability Index. Spine. 2000; 25:2940-2953.

3. Dr. Indradeva Tripathi, Chakradatta, Chaukambha Sanskrit Pratishthan, Niruhadhikara, 2019, Chapter 73/32:455

4. Acharya YT, editor. Charaka Samhita of Agnivesha, Varanasi: Chaukambha Sanskrit Sansthan; Sutrasthana. Ch.3, Ver. 18. 2016:28.

5. H Shirota, M Goto, K. Katayama, Application of adjuvant-induced local hyperthermia for evaluation of anti-inflammatory drugs. The Journal of Pharmacology and Experimental Therapeutics. 1988, 247(3):1158-63.

6. Brosseau L, KA Yonge, Robinson V, Marchand S, Judd M, Wells G, et al. Thermotherapy for treatment of osteoarthritis. The Cochrane Database of Systemic Reviews, 2003(4):CD004522

\section{Source of Support: Nil \\ Conflict of Interest: None Declared}

How to cite this URL: Swathi N. \& Anup B. Thakar: Evaluation of Effect Of Vaitarana Basti And Upanaha Sweda In Low Back Ache (Kati Graha) Due To Sacroilitis: A Case Review. International Ayurvedic Medical Journal \{online\} 2020 \{cited October, 2020\} Available from: http://www.iamj.in/posts/images/upload/4917 4919.pdf 